\title{
The Impact of Monetary Policy on Agricultural Development In Nigeria (1970-2010)
}

\author{
Dr. Christopher Ehinomen ${ }^{1}$ and Mr. Akorah Chukwudi Charles ${ }^{2}$ \\ Department Of Economics And Business Studies, Redeemer's University, Redemption City, K/M 46/85 Lagos - \\ Ibadan Expressway, Mowe, Ogun State, Nigeria.
}

\begin{abstract}
The need to correct the existing structural distortions in Nigerian agricultural sector and put the economy on the path of sustainable growth is compelling. This raises the question of what monetary policy to adopt to develop the agricultural sector in order to realize the potentials of the sector. The broad objective of this study is to assess the effectiveness of the monetary policies in promoting agricultural development in Nigeria. Secondary data were used in this study. The data were sourced from the publications of Central Bank of Nigeria (CBN) such as CBN statistical bulletin, CBN statements of Accounts and annual reports, as well as Federal Office Statistics (now National Bureau of Statistics) Publications of relevant years. The relevant variables for which data were sourced include: Minimum Re-discount Rate (MRR), Treasury Bill Rate (TBR), broad money supply $\left(M_{2}\right)$, agricultural sector output and index of agricultural production at 1990 base year for the period 1970 to 2010. The method of analysis used in this study is the Ordinary Least Square method (OLS) using E-view. The results of the analyses showed that although CBN's monetary policies play crucial role in influencing the level of agricultural productivity in the country, it has not recorded significant progress in terms of providing enabling environment for better performance in the agricultural sector. It is consequently recommended that the Central Bank of Nigeria should introduce more monetary instruments that are flexible enough to meet the ever-growing financial sector in order to attract both domestic and foreign investors; while more stringent punishment should be made for non-compliance to the monetary policies by financial institutions.
\end{abstract}

Keywords: Monetary policy, Agricultural productivity, Least Square, Monetary Instruments, and Investment.

\section{Introduction}

The attainment of a high level of economic growth has always been seen as the reason for economic policy making in most countries of the world; be it in developed, underdeveloped or developing economies. In Nigeria for example, planners since independence have made series of painstaking efforts to set out macroeconomic goals with a view to achieving high level of economic development through the formulation and implementation of development plans. The goals of the policies vary from one plan to another; portraying changes in the economic environment and circumstances. It should be noted however, that monetary policy formulation and execution is a major activity of the Central Bank of Nigeria. To achieve balanced and steady economic growth and development, and to instill some sanity into a country's financial system, the need for monetary policy becomes inevitable. Monetary policy can be defined as the combination of measures designed to control the supply of money and credit conditions in an economy for the purpose of achieving macroeconomic goals. Monetary policy could either be contractionary or expansionary, depending on the prevailing economic conditions and circumstances. Monetary policy instruments can be classified into two categories. These include the quantitative tools such as open market operation (OMO), discount rates, cost tools, stabilization securities, direct regulation of interest rates, liquidity ratio, etc. The second category includes the direct tools; moral suasion, credit guideline and so on.

Nigeria's agricultural sector has been faced with several emerging problems which constrained the full realization of its full potentials. These problems include; inadequacies in the supply and delivery of farm inputs, shortage of working capital, low level of technology, diseases and pest infestation, poor post-harvest processing, poor storage facilities, inconsistent and poorly conceived government policies, problems of pests and diseases, negative attitude of people towards farming due to low reward, inadequate agricultural education and extensions, poor transportation, lack of credit facilities, irrigation problems, lack of investment, lack of basic infrastructure, inadequate fertilizers and farm implements, environment hazards, labour and land use constraints. Most of these problems could be solved if appropriate monetary policy are put in place. In a bid to address the problems, the Nigerian government, from 1975 became directly involved in the commercial production of food crops. Several large scale agricultural projects specializing in the production of grains, livestock, dairies and animal feeds, etc. were established.

Interest rate structure was employed principally to direct 'cheap' credit to specific sectors such as agricultural sector. This was done by consistently stipulating relatively lower interest rates for loans and 
advances of the sector. As parts of the efforts of the monetary authorities to alleviate the burden of repayment of agricultural loans by farmers, the grace periods for the repayment was evolved in 1984. The grace period for loans granted to small-scale peasant farmers and producers of seasonal cash crops; such as groundnuts, was fixed at one year, four years for loans to livestock farmers as well as those engaged in the production of crops with relatively long gestation periods for example rubber, palm trees and cocoa. For medium and large scale mechanized farming, the grace period was five (5) years.

Despite these efforts of government in boosting agricultural production, the sector is not witnessing significant development. Hence, this study assesses the effectiveness of the monetary policies in promoting agricultural development in Nigeria. The structure of this paper is as follows: section II deals with the theoretical framework and reviews relevant literature for the study. Section III contains the model specification and empirical results of the study. In section IV the paper concludes with summary and policy implications of the study.

\section{Theoretical Framework And Review Of Literature.}

There are the monetarist viewpoints represented by Friedman (1969) [1], the Keynesian school and lastly the one represented by Raddiffe (1963)[2]. Friedman (1969) is of the view that changes in the stock of money are closely related to changes in the price level and through it, on other general economic aggregates. But, precision and rigidity in this relationship is distorted because of changes in output and the amount of money that the public desires to hold relative to its income. The effects of these changes are not to be seen as instantaneous as there is sometimes lag between the application of the monetary policy and its effectiveness.

Keynesian viewpoint is that money plays a role in the determination of real output, general price level and other Macro-economic variables. According to this school of thought, national income depends on the interplay between such variables as expected rate of profit and interest. The rate of interest is a function of the supply of and the demand for money. Equilibrium income depends on two conditions in this model, that is: planned savings must be equal to planned investment, and at any point in time, supply of money must equal demand for money. But both savings, investment, demand for and supply of money is influenced by changes in the rate of interest. Within this context, monetary policy will consist of altering the rate of interest to achieve the desired trend in the economy. The effectiveness of monetary policy will then depend on the interest elasticity of demand for money. This also dictate the effectiveness or otherwise, in combating depression as well as inflation.

The third viewpoint represented by Raddiffe (1963) is a variant of the Keynesian school of thought. A distinction is made between the demand for money and the demand for liquidity. These two types of demand are not the same thing because there exist interest yielding money substitutes, which people can easily turn to cash whenever they want. As a result of this, whatever is done to change the demand for money may be less effective than expected. because it is the demand that will respond to interest rate changes. The amount of money desired may not increase, if the interest rate falls even though the amount of liquidity increases. Part of the accumulation of liquidity is likely to take the form of interest bearing near-money instead of non-interest yielding cash. The results obtained from changing the money supply depend on shifts in the demand for money and not on shortrun interest elasticity of demand for money. Therefore, for monetary policy to be effective it has to address itself to the control of the volume, cost and direction of liquidity, rather than money supply in the economy.

Traditionally, there are other three tools of control; they are (i) open market operations, (ii) the legal reserves ratio and (iii) the bank rate. The recent additions are special deposit and stabilisation security. They are called quantitative controls because their main aim is to regulate the quantity of money in circulation and the volume of credit that could be created by the commercial banking system, since these credits constitute part of the money supply.

\subsection{Review of Literature.}

Friedman, M. (1969) defines monetary policy as the action taken by the monetary authorities usually the Central Bank to affect monetary and other financial conditions through influence over the availability and cost of credit in pursuit of the broad objectives of sustainable growth of output, price stability and a healthy balance of payments position. The discretionary control of the money stock to him involves the expansion or contraction of money and influencing interest rate to make money cheaper or more expensive depending on the prevailing economic conditions and thrust of policy. He went further to classify the instruments of monetary control into two broad categories - direct and indirect instruments. Under a system of direct monetary control, the Central Bank uses some criteria to determine monetary, credit and interest rate targets that would achieve the goals of economic policy. In a regime of indirect monetary control, the monetary base (specifically bank reserves) is managed while the market is left to determine interest rates and credit allocation.

Gertler and Gilchrist (1991) [3], established the existence of the lending channel by studying the response of small manufacturing firms to changes in monetary policy. The results of their analysis indicated that, in periods of contractionary monetary policy, (i) lending to small firms declines, (ii) small firms react more to changes in 
bank-related aggregate (e.g. broad money) than large firms. According to Tobin's (1978) [4], view of transmission mechanism, an increase in money supply leads to assets substitution between corporate bonds, equities, commercial paper and banks deposits. He also indicated that monetary policy affects the economy through liquidity constraints and credit control. Borio (1995) [5], investigated the credit channel of monetary policy by examining the structure of credit to the non-government sector in fourteen industrialised countries and factors influencing it. He found that the structure of credit was largely determined by interest rate and factors affecting the availability of credit such as collateral value and rationing, defined as "refusal to grant as much credit as is demanded on the observed interest and non-interest terms".

Shaw (1973) [6], defines monetary policy as "any conscious action undertaken by the monetary authority to change the quantity and availability or cost of money", while Duncan and Sidrauski (1971) [7], emphasised that government monetary policy directly affect only the assets market given the assumption that savings are insensitive to interest rate. In the words of Jokomba and Fasanu (1998) [8], monetary policy was refer to as the combination of measures designed to regulate the value, supply and cost of money in an economy in consonance with the level of economic activity. They went further to say that it is difficult to link monetary policy actions directly with overall economic performance not only because of the lags between actions and the outcomes but also because of the effects of other economic policies; fiscal and income policy measures.

Ufodiama (1999) [9], explains that monetary policy, which includes financial policy, refers to the deliberate action of the monetary authority to control the money supply and general credit available in the economic system. There are two major control mechanisms of monetary policy used by Central Banks at any point in time and this control mechanism are usually referred to as tools/instruments of monetary policy and they have effects on the proximate targets. Monetary instruments can be direct or indirect. The direct instruments include aggregate credit ceilings, deposit ceiling, exchange control, restriction on the placement of public deposit, special deposits and stabilisation securities while indirect instruments include Open Market Operation (OMO), cash reserve requirement, liquidity ratio, minimum discount rate and selective credit policies. Monetary policy has vital roles in the short-run i.e. it is used for counter-cyclical output stabilisation, while in the long run, it is used to achieve the macro-economic goals of full employment, price stability, rapid economic growth and balance of payments equilibrium. Under SAP, monetary and financial policies were programmed to play a dual role. For economic growth and stabilisation purposes, there was to be tight monetary policy to complement a more disciplined fiscal policy in order to reduce domestic demand and reduce inflationary pressures. Anyanwu (1996) [10], opines that monetary Policy in general refers to the combination of measures designed to regulate the value supply and cost of money in an economy, in consonance with the expected level of economic activity. Ahmed (1991) [11], opines that monetary policy is a central bank's actions to influence the availability and cost of money and credit, as a means of helping to promote national economic goals. Eze (1993) [12], stresses that monetary policy regulates the supply of money and the cost and availability of credit in the economy. It deals with both the lending and borrowing rates of interest for commercial banks. The monetary policy aims to maintain price stability, full employment and economic growth. The Central Bank of Nigeria is responsible for formulating and implementing monetary policy. It can increase or decrease the supply of currency as well as interest rate, carry out open market operations, control credit and vary the reserve requirements. Kogar (1995) [13], argues that monetary policy is an effective instrument in relation to influencing demand. He noted that it is crucial to generating an environment for sustainability of lower inflation. He examined the relationship between financial innovations and monetary control and concluded that in a changing financial structure Central Banks cannot realise efficient monetary policy without setting new procedures and instruments in the long-run, because profit seeking financial institutions change or create new instruments in order to evade regulations or respond to the economic conditions in the economy.

Canetti and Greene (2000) [14], investigated whether inflation is due primarily to excessive monetary growth or to exchange rate depreciation. The results of the study support the view that both exchange rate movements and monetary expansion affected consumer price changes in a number of Sub-Saharan African countries. Both the bivariate and trivariate Granger causality tests suggest that exchange rates had a significant causal impact on prices in Sierra Leone, Tanzania, and Zaire. The same was true in the bivariate tests for Kenya and in the trivariate tests for the Gambia. As for money, bivariate and trivariate Granger tests identified money as having a significant causal effect on prices in the Gambia, Sierra Leone, and Uganda. In addition, there was evidence of causality from money to prices in the bivariate tests for Somalia. Finally, money appeared to have a significant causal impact on exchange rates in Zaire, suggesting that the underlying causality in that country was from money to prices, perhaps via adjustments in the exchange rate. In two countries, Nigeria and Zambia, Granger causality tests identified neither money nor exchange rates as significantly causing prices. At less-thanconventional levels of significance, however, there was some indication of causality from money to prices in Nigeria and, for trivariate analysis, from exchange rates to prices in Zambia.

Iyoha and Oriakhi (2002) [15], opine that monetary policy should be such as to prevent inflation that is often a source of instability and which then leads to a reduction in investment. They argue that monetary and 
credit policy should be designed to bring about a low but positive real interest rate. A low positive interest rate will encourage capital accumulation. Financial repression should be eschewed and a deregulated financial environment embraced. They said that an important aim of monetary and credit policy should be a sound banking system kept in check with strong prudential regulation and supervision.

Nnanna (2001) [16], examines that the evolution of monetary policy in Nigeria in the past four decades and observed that though, the Monetary management in Nigeria has been relatively more successful during the period of financial sector reform, the socio-economic and political milieu, including the legal framework under which the Central Bank of Nigeria has operated, was the critical factor that influenced the outcome of monetary policy. He further noted that the granting of instrument autonomy to the CBN has enhanced its operational efficiency, in terms of its ability to achieve its key objective of monetary policy, namely price stability.

Busari et al. (2006) [17], examine the implications of the exchange rate regime on the ability of monetary policy to stabilize the economy. They found maintained that monetary policy stimulates growth better under a flexible rate regime but it is accompanied by severe depreciation, which could destabilize the economy. In other words, they opined that monetary policy would better stabilize the economy if it is used to target inflation directly than be used to directly stimulate growth. They suggested that other policy measures and instruments are required to complement monetary policy in macroeconomic stabilization.

Batini (2004) [18], argues that the implementation of monetary policy in Nigeria has been complicated by a number of factors, including fiscal largesse, lack of operational autonomy of the central bank, insufficient and low-quality statistics, a weak transmission mechanism, and a weak financial system. His analysis revealed that neither the stable prices/free float nor the fixed exchange rate solutions are particularly appealing for Nigeria in the long run. He argued that inflation targeting with a free float still seems to be a superior option on various grounds.

Folawewo and Osinubi (2006) [19], investigated how monetary policy objective of controlling inflation rate and intervention in the financing of fiscal deficits affect the variability of inflation and real exchange rate. The analysis is done using a rational expectation framework that incorporates the fiscal role of exchange rate. It was shown in the paper that the effort of monetary policy at influencing the finance of government fiscal deficit through the determination of the inflation-tax rate affects both the rate of inflation and the real exchange rate, thereby causing volatility in their rates. The paper revealed that inflation affects volatility of its own rate as well as the rate of real exchange. The policy implication of the paper is that monetary policy should be set in such a way that the objective it is to achieve is well defined.

Sanusi (2002) [20], opines that the ability of the CBN to pursue an effective monetary policy in a globalised and rapidly integrated financial market environment depends on several factors. These include: instituting appropriate legal framework, institutional structure and conducive political environment, which allows the Bank to operate with reference to exercising its instrument and operational autonomy in decision- making; the degree of coordination between monetary and fiscal policies to ensure consistency and complementarity; the overall macroeconomic environment, including the stage of development, depth and stability of the financial markets as well as the efficiency of the payments and settlement systems; the level and adequacy of information and communication facilities; and the availability of consistent, adequate, reliable, high quality and timely information to the Bank. He stressed that seeking a proper role for monetary policy in promoting strong and sustainable growth in a stable macroeconomic environment in Nigeria is an on-going challenge for the Central Bank.

\subsubsection{Agricultural Financing in Nigeria}

Agricultural finance is basically related to agricultural development. It is based on the economic belief that agricultural development is a process that involves adoption by farmers of new production practices and the acquisition of new input materials. Unfortunately, the rural capital market cannot supply the needed funds to finance such innovations. As a result, agricultural development in Nigeria as in similar developing nations is stunted. The problem of agricultural finance then becomes that of finding adequate fund for agricultural development, identifying the right farmers who could benefit from such fund, extending such fund to the right farmers on terms acceptable to both the sponsor and the receiving farmers. The programmes discussed in this section are the Nigerian farm credit corporation and the New Programmes.

The Nigerian Agricultural Cooperative and Rural Development Bank (NACRDB) has been restructured and is being recapitalized for greater efficiency and to provide credits to individual farmers, cooperatives societies/bodies for all classes of agricultural projects. The Bank is also concentrating on the promotion of its popular "group lending scheme" whereby a much higher proportion of the active farming population is being reached by its retail outlets across its six Zonal offices. The Bank Management is supporting the new policy orientation of the present administration regarding poverty alleviation by emphasizing micro credit. The Bank is now strongly committed to the promotion of grass roots based, small and medium farming activities in the country. The ongoing injection of N50 billion equity shares into NACRBD by the Federal Government is to 
empower the Bank to meet the challenges of poverty alleviation and food production through timely disbursement of credits. The bank is also supporting the promotion of Animal Traction and Hand Tool Technology. It has instituted several credits and savings schemes for farmers and rural dwellers that constitute about $70 \%$ of the nation's population.

\subsubsection{The Agricultural Credit Guarantee Scheme (ACGS)}

The Agricultural credit guarantee scheme was established in 1977. The act provides for a fund of N100 million subscribed to by then federal military government $(60 \%)$ and the central bank of Nigeria (40\%) for the year ended 31st December 1980. In 2001, the capital base of the fund was increased to N3.0 billion in order to enhance its coverage and performance. The purpose of the fund is to provide guarantee in respect of loans granted by commercial and merchant banks for agricultural purposes with the aim of increasing the level of bank credit to agricultural sector. In order to guard against the misuse of the funds, the decree provided that in the event that such loans are used to purchase livestock, machinery or farming equipment, the loan should not be paid to the borrower but to the supplier who should furnish the Bank with the document in evidence of the delivery of the items. The scheme has granted over N3.3 billion to beneficiaries since inception. There is the tendency for all investors to use the credit for purpose other than with it was granted. There is the temptation to utilize the credit outside any planned programme with the result that the farmer may push himself into overexpansion, over trading, extravagant living or even fraudulent or highly speculative ventures. There is also the endemic problem with most of the peasant farmers concerning their lack of knowledge of even the sources of credit or terms of loans owing to the low level of literacy among the preponderance of the full time farmers, and also due to inadequate communication facilities in the country, most of the farmers are not in a position to indicate or understand the names, locations and types of existing credit resources, much less of the import of interest rates which apply to farm loans. Again certain credit institutions notably banks could want to be satisfied with the quality of the management of any venture into which they are being called upon to invest. But unfortunately very few farmers in Nigeria possess the necessary managerial skill or the technical knowledge which could adequately meet the standard expected by these credit institutions.

Finally while small farmers have been exempted from fulfilling the obligation in as far as loans under the ACGSF is concerned, there is nothing to indicate that the banks do not demand such a report from the small farmers for loans outside the guarantee scheme. Available statistics shows that these banks have not made any significant impact since inception. For instance, the banks failed to meet the prescribed minimum, except in 1979 when they exceeded the minimum by 5 percent. Again it is not possible to classify commercial bank credit to agriculture, but one could indicate that greater part of the loans have gone to the bigger, as opposed to the smaller farmers, and may have been for marketing function rather than production functions. This indicates that the small farmers are still left out. The problem persists and hence constitutes a trait to the economic development of the country in ensuring balance growth of the economy. With respect to the Nigerian Agricultural and Co-operative Bank, emphasis seem to have been placed on loans to co-operative organizations rather than small scale farmers. They always complain of loan shortage to meet their obligations. The point here is that the bank allocates greater share of its loan to co-operatives and the government and hence the greater part of the 90 percent of the Nigerian farmers still have no access to a dependable source of agricultural credit. The fact is that the nation will continue to wallow in the ocean of economic backwardness since the greater percentage of the population is still in the poverty stage.

\subsubsection{The National Agricultural Policy}

In an attempt to tackle the problems facing the Agricultural Sector in Nigeria, Government has put in place the National Agricultural Policy, which was jointly formulated by the national stakeholders and International Development Partners and approved by the Federal Government in 2002. The major components of the National Agricultural Policy feed the National Economic Empowerment and Development Strategy (NEEDS) document. Specifically, the National Agricultural Policy assigns supportive roles to the government, while investments in the sector are left to the private sector initiative. The broad objectives of the National Agricultural Policy include: Promotion of self-sufficiency in food and raw materials for industries; recognition that agriculture is business, hence a private sector concern where the role of government is to facilitate and support private sector initiatives; promoting reliance on local resources; diversification of the sources of foreign exchange earnings through increased agricultural exports arising from adoption of appropriate technologies in food production and distribution, which specifically responds to the needs of women, bearing in mind that they constitute over $50 \%$ of the labour force in agriculture.

\subsubsection{Agricultural Credit Support Scheme (ACSS)}

The Federal Government and the Central Bank of Nigeria have initiated the establishment of an Agricultural Credit Support Scheme (ACSS), with the active support and participation of the Bankers' 
Committee. The Scheme had a fund of N50.0 billion (Fifty billion naira) contributed by the following participants;

i. N30 billion (N1 billion each) from the Universal banks. N5 billion additionally from the 5 big banks i.e. First Bank, Union Bank, UBA, Zenith and GTB;

ii. N6 billion from SMEEIS;

iii. N5 billion from NACRDB;

iv. N2.5 billion from ACGSF;

v. N0.7 billion from debt relief (MDG);

vi. N200 million each from the State Governments. (N 7.2billion).

The purpose of the ACSS is to develop the agricultural sector of the Nigerian economy by providing credit facilities to farmers at single digit interest rate. This is to enable farmers exploit the untapped potentials of the sector with a view to reducing the cost of agricultural production, and increase output on a sustainable basis. These efforts are expected to lead to fall in prices of agricultural produce, especially food items, thereby leading to reduction in inflation rate, generate surplus for export, diversify the revenue base and increased foreign exchange earnings for the country. The willingness of deposit money banks to dedicate part of their loan able funds to participate is indicative of their readiness to actively promote the growth and development of the real sector of the economy. As custodians of shareholders/ depositors funds, participating banks are expected to exhibit high degree of due diligence in appraising credit requests under the ACSS as is applicable in their normal course of business.

\section{Model I}

\section{Hypotheses}

$\mathrm{H}_{0}$ - That monetary policy instruments do not affect agricultural output in Nigeria.

$\mathrm{H}_{1}$-That monetary policy instruments affect agricultural output in Nigeria.

\section{Model II}

$\mathrm{H}_{0}$-That monetary policy instruments do not affect index of agricultural production in Nigeria.

$\mathrm{H}_{1}$-That monetary policy instruments affect index of agricultural production in Nigeria.

Secondary data were used in this study. The data were sourced from the publications of Central Bank of Nigeria (CBN) such as CBN statistical bulletin, CBN statements of Accounts and annual reports, as well as Federal Office Statistics (now National Bureau of Statistics) Publications of relevant years. The relevant variables for which data were sourced include: Minimum Re-discount Rate (MRR), Treasury Bill Rate (TBR), broad money supply $\left(\mathrm{M}_{2}\right)$, agricultural sector output and index of agricultural production at 1990 base year for the period 1970 to 2010.

The method of analysis used in this study is the Ordinary Least Square method (OLS) using E-view.

The two models to capture the impact of monetary policy on Nigerian agricultural development are stated below with the independent variables as Minimum Re-discount Rate (MRR), Treasury Bill Rate (TBR), broad money supply (M2), while the dependent variables are output of the agricultural sector and index of agricultural production at 1990 base; so that:

\section{Model I}

$$
\text { out } t_{\text {agt }}=a_{0}+a_{1} m r r_{t-1}+a_{2} t b r_{t-1}+a_{3} m_{2 t-1}+u_{i}
$$

Where out $t_{\text {agt }}$ - Output of the Agricultural Sector for current year

$$
m r r_{t-1} \text { - Minimum Rediscount Rate for previous year }
$$

$t b r_{t-1}$ - Treasury Bill Rate for previous year

$m_{2 t-1} \quad$-Broad Money Supply for previous year

$\mathrm{a}_{0}, \mathrm{a}_{1}, \mathrm{a}_{2}, \mathrm{a}_{3}, \mathrm{a}_{4}$ - Constants

$u_{i}$-Error term

\section{Model II}

$$
\text { indagr }{ }_{1990}=b_{0}+b_{1} \text { mrr }_{t-1}+b_{2} t b r_{t-1}+b_{3} m_{2 t-1}+u_{i}
$$

Where indagr ${ }_{1990}$-Index of Agricultural Production at 1990 base year

$$
\begin{array}{r}
m r r_{t-1} \quad \text { - Minimum Rediscount Rate for previous year } \\
t b r_{t-1} \quad \text {-Treasury Bill Rate for previous year }
\end{array}
$$


$m_{2 t-1} \quad$-Broad Money Supply for previous year

$\mathrm{b}_{0}, \mathrm{~b}_{1}, \mathrm{~b}_{2}, \mathrm{~b}_{3}, \mathrm{~b}_{4}$-Constants

$u_{i}$-Error term

\section{Model I}

out $t_{\text {agt }}=a_{0}+a_{1} m r r_{t-1}+a_{2} t b r_{t-1}+a_{3} m_{2 t-1}+u_{i}$

It is expected that $a_{0}>0, a_{1}>0, a_{2}>$, and $a_{3}<0$

\section{Model II}

indagr $r_{1990}=b_{0}+b_{1} m r_{t-1}+b_{2} t b r_{t-1}+b_{3} m_{2 t-1}+u_{i}$

It is expected that $b_{0}>0, b_{1}>0, b_{2}>0$, and $b_{3}<0$

\subsection{Unit Root Test}

We employ the Augmented Dickey-Fuller unit root test. The result of the unit root test is given below:

Table Unit root test

\begin{tabular}{|c|c|c|c|}
\hline VARIABLE & INTERCEPT & T-STATISTICS & Prob. Value \\
\hline LOGOUTAGR & $1^{\text {ST }}$ DIFFERENCE & -8.025966 & 0.0000 \\
\hline LOGINDAGR1990 & $1^{\text {ST }}$ DIFFERENCE & -7.066344 & 0.0000 \\
\hline LOG $m r_{t-1}$ & $1^{\text {ST }}$ DIFFERENCE & -7.428226 & 0.0000 \\
\hline LOG $b r_{t-1}$ & $1^{\text {ST }}$ DIFFERENCE & -6.692065 & 0.0000 \\
\hline LOG $m_{2 t-1}$ & $1^{\text {ST }}$ DIFFERENCE & -3.762214 & 0.0067 \\
\hline
\end{tabular}

The table above shows the result of the unit root test. The degrees of integration of the variables employed in the test were estimated using the Augmented Dickey-Fuller unit root test. Going by the results, at $1^{\text {st }}$ difference forms, the ADF test suggests that the output of the agricultural sector, index of agricultural production, minimum re-discount rate (MRR), treasury bill rate (TBR) and broad money supply (M2) are stationary at $5 \%$.

\subsection{Chow Forecast Test}

The Chow forecast test estimates two models - one using the full set of data, and the other using a long sub period. A long difference between the two models casts doubt on the stability of the estimated relation over the sample period. Going by the results of the chow forecast test in the first and second models presented in the appendix, the independent variables; Minimum Re-discount Rate (MRR), Treasury Bill Rate (TBR) and Broad Money Supply (M2) are not statistically significant, i.e. they are not statistically different from zero. This shows that the time difference (i.e. pre-SAP and post- SAP) do not really have any significant effect on the effectiveness of monetary policy on agriculture.

\subsection{Presentation of Regression Results \\ Model I \\ Dependent variable: LOGOUTAGR}

\begin{tabular}{|c|c|c|c|c|}
\hline Variable & Coefficient & Std. Error & t-Statistics & Prob. \\
\hline C & 0.594340 & 0.098250 & 6.049679 & 0.0000 \\
\hline LOGmrr $r_{t-1}$ & 0.111133 & 0.611573 & 0.181716 & 0.8568 \\
\hline LOG $t b r_{t-1}$ & 0.160251 & 0.470413 & 0.340660 & 0.7353 \\
\hline LOG $_{2 t-1}$ & 0.192157 & 0.033346 & 5.762443 & 0.0000 \\
\hline
\end{tabular}

$$
\begin{aligned}
& \text { out }_{a g t}=a_{0}+a_{1} \text { mrr }_{t-1}+a_{2} t b r_{t-1}+a_{3} m_{2 t-1}+u_{i} \\
& \text { out }_{a g t}=0.594340+0.111133 \log \operatorname{mr}_{\mathrm{t}-1}+0.160251 \log \mathrm{tbr}_{\mathrm{t}-1}+0.192157 \log \mathrm{M}_{2 \mathrm{t}-1}
\end{aligned}
$$

R-squared $\quad-0.842828$

Adjusted R-squared - 0.830085

Prob(F-statistic) - 66.13710

Durbin-Watson stat $\quad-0.545256$ 
Model II

Dependent variable: LOGINDAGR1990

\begin{tabular}{|c|c|c|c|c|}
\hline Variable & Coefficient & Std. Error & t-Statistics & Prob. \\
\hline $\mathrm{C}$ & 1.215232 & 0.073752 & 16.47732 & 0.0000 \\
\hline LOG $m r r_{t-1}$ & -0.696457 & 0.459082 & -1.517066 & 0.1377 \\
\hline LOGt $b r_{t-1}$ & 0.546005 & 0.353119 & 1.546235 & 0.1306 \\
\hline LOG $m_{2 t-1}$ & 0.201182 & 0.025032 & 8.037106 & 0.0000 \\
\hline
\end{tabular}

$$
\begin{aligned}
& \text { out }_{a g t}=a_{0}+a_{1} m r r_{t-1}+a_{2} t b r_{t-1}+a_{3} m_{2 t-1}+u_{i} \\
& \text { out } t_{a g t}=1.215232-0.696457 \operatorname{logmrr}{ }_{t-1}+0.546005 \log t b r_{t-1}+0.201182 \log M_{2 t-1}
\end{aligned}
$$

R-squared $\quad-0.842891$

Adjusted R-squared - 0.830153

Prob(F-statistics) $\quad-66.16847$

Durbin-Watson stat -0.544613

\subsection{Interpretations of Results \\ Model I}

Going by the results of the regression, there is a positive relationship between the output of the agricultural sector and the aggregate monetary policy instruments used in the analysis. This result shows that some monetary policy instruments have been effective in stimulating agricultural performance over the period under consideration. The theoretical t-value at $5 \%$ level of significance with thirty-seven (37) degree of freedom is 1.697. The computed t-values for Minimum Re-discount Rate (MRR) and Treasury Bill Rate (TBR) are less than the theoretical t-value, we therefore accept the null hypothesis and reject the alternative hypothesis. This indicates that the parameter estimates are not statistically significant. However, the computed t-value for Money Supply (5.762443) is greater than the theoretical t-value, therefore, we reject the null hypothesis and accept the alternative hypothesis. This implies that the parameter estimate (i.e. money supply) is statistically different from zero i.e. it is a relevant variable in the determination of the output of the agricultural sector in Nigeria.

The adjusted coefficient of determination $\left(\mathrm{R}^{2}\right)$ gives 0.830 or $83.0 \%$. This means that the output of the agricultural sector is $83 \%$ attributable to the changes in the independent variables i.e Minimum Re-discount Rate (MRR), Treasury Bill Rate (TBR), and Money supply $\left(\mathrm{M}_{2}\right)$, but mostly driven by the influence of the money supply.

The calculated F-value (66.13710) is greater than the critical F-value at 5\% level of significance. We therefore reject the null hypothesis and accept the alternative hypothesis. This signifies that the overall relationship between the output of the agricultural sector and the selected monetary policy instruments is significant. This result reveals to us that the monetary policies of the Central Bank of Nigeria have impacted on the performance of the agricultural sector in terms of its output. It means that the monetary policies of the CBN are effective in respect of the development of the agricultural sector.

The computed D.W. (Durbin-Watson) in model one is 0.545256 , which reveals to us that there is some degree of positive autocorrelation between the output of the agricultural sector, Minimum Re-discount Rate, Treasury Bill Rate, and Money supply in Nigeria. Thus, in order to take into account serial correlation in the above results, the autoregressive ' $\operatorname{ar}(1)$ ' was used. Therefore, the corrected result is stated below:

Dependent variable: LOGOUTAGR

\begin{tabular}{|c|c|c|c|c|}
\hline Variable & Coefficient & Std. Error & t-Statistics & Prob. \\
\hline C & 0.464275 & 0.214251 & 2.166974 & 0.0371 \\
\hline${\text { LOG } m r r_{t-1}}$ & 0.098355 & 0.375015 & 0.262270 & 0.7947 \\
\hline${\text { LOG } t b r_{t-1}}^{\text {LOG } m_{2 t-1}}$ & 0.020699 & 0.282563 & 0.073148 & 0.9421 \\
\hline$A R(1)$ & 0.241624 & 0.042380 & 5.701320 & 0.0000 \\
\hline
\end{tabular}

R-squared

$-0.936518$

Adjusted R-squared - 0.929263

F-statistic $\quad-129.0842$

Prob(F-statistics) $\quad-0.000000$

Durbin-Watson stat -2.234436

Inverted AR Roots $\quad-.70$ 
Given the regression results, there is still a positive relationship between the output of the agricultural sector and all monetary policy instruments used in the analysis. The t statistics of this estimation shows that the Minimum Re-discount Rate (MRR) and Treasury Bill Rate (TBR) estimates are still not statistically significant. Money Supply $\left(\mathrm{M}_{2}\right)$ is a significant determinant of agricultural output in Nigeria. The computed t-value for Money Supply (5.701320) is greater than the theoretical t-value which means that money supply is a relevant variable in the determination of the output of the agricultural sector in Nigeria.

The adjusted coefficient of determination $\left(\mathrm{R}^{2}\right)$ gives 0.94 or $94.0 \%$. This means that the output of the agricultural sector is $94 \%$ attributable to the changes in the independent variables; Minimum Re-discount Rate (MRR), Treasury Bill Rate (TBR), and Money supply $\left(\mathrm{M}_{2}\right)$.

The calculated F-value (129.0842) is greater than the critical F-value at 5\% level of significance which signifies that the overall relationship between the output of the agricultural sector and the selected monetary policy instruments is significant.

The Durbin-Watson value now shows negative autocorrelation. The computed Durbin-Watson is now (2.234436) which indicate the absence of autocorrelation.

\section{Model II}

From the results of the second regression, there is positive relationship between the index of agricultural production, Treasury Bill Rate (TBR), and Money supply $\left(\mathrm{M}_{2}\right)$. But in the case of Minimum Rediscount Rate (MRR), it varied negatively with the index of agricultural production. Money supply $\left(\mathrm{M}_{2}\right)$ is statistically significant. We therefore reject the null hypothesis and accept the alternative hypothesis. Treasury Bill Rate and Minimum Re-discount Rate are not statistically significant; as such the alternative hypothesis is rejected. The theoretical t-value at 5\% level of significance with thirty-seven (37) degree of freedom is 1.697. Since the critical t-value is less the calculated t-value for money supply, we reject the null hypothesis and accept the alternative hypothesis. This means that money supply affects the index of agricultural production. But the opposite is the case for Minimum Re-discount Rate and Treasury Bill Rate because their calculated t-values are less than the critical t-value. Therefore the null hypothesis is accepted while the alternative hypothesis is rejected.

In this model the adjusted coefficient of determination $\left(\mathrm{R}^{2}\right)$ gives 0.84 or $84 \%$. This shows that the regression analysis between the index of agricultural production and the selected monetary policy instruments is approximately $84 \%$ significant, that is to say the variations in the index of agricultural production is $84 \%$ attributable to the changes in the independent variables which are Minimum Re-discount Rate, Treasury Bill Rate, and Money supply.

The calculated F-value (66.16847) is greater than the critical F-value at 5\% level of significance. We therefore, reject the null hypothesis and accept the alternative hypothesis. This means that the overall regression between the index of agricultural production, Minimum Re-discount Rate and Treasury Bill Rate, and Money supply is statistically significant.

The computed D.W. (Durbin-Watson) in model two is 0.544613 , which reveals to us that there is some degree of positive autocorrelation between the index of agricultural production and the independent variables; Minimum Re-discount Rate, Treasury Bill Rate, and Money supply in Nigeria.

In order to take care of the serial correlation in the above results, the autoregressive ' $\operatorname{ar}(1)$ ' was used. Therefore, the corrected result is stated below:

\section{Dependent variable: LOGINDAGR1990}

\begin{tabular}{|c|c|c|c|c|}
\hline Variable & Coefficient & Std. Error & t-Statistics & Prob. \\
\hline C & 1.023038 & 0.140664 & 7.272910 & 0.000 \\
\hline${\text { LOG } m r r_{t-1}}^{\text {LOGtbr-1 }} r_{t-1}$ & -0.251592 & 0.271303 & -0.927344 & 0.3601 \\
\hline LOG $m_{2 t-1}$ & 0.185975 & 0.203162 & 0.915402 & 0.3662 \\
\hline$A R(1)$ & 0.213951 & 0.027770 & 7.704309 & 0.0000 \\
\hline
\end{tabular}

\footnotetext{
R-squared $\quad-0.943590$

Adjusted R-squared - 0.937143

F-statistics $\quad-146.3643$

Prob(F-statistics) $\quad-0.000000$

Durbin-Watson stat $\quad-1.969890$

Inverted AR Roots - $\quad .66$
} 
Going by the regression results, the Minimum Re-discount Rate still varies negatively with the index of agricultural production while the relationship between the index of agricultural production and the other independent variables, i.e Treasury Bill Rate (TBR) and Money Supply $\left(\mathrm{M}_{2}\right)$ is a positive one.

The adjusted coefficient of determination $\left(\mathrm{R}^{2}\right)$ gives 0.94 or $94 \%$. This shows that the regression analysis between the index of agricultural production and the selected monetary policy instruments is approximately $94 \%$ significant.

The Durbin-Watson value now shows negative autocorrelation. The computed Durbin-Watson is now (1.969890) which indicates the absence of autocorrelation.

\subsection{Discussion of Results}

The regression analyses produced mixed results. Although, the results of the first and second regression analysis revealed that the selected monetary policies ; Minimum Re-discount Rate, Treasury Bill Rate, and Money supply have stimulated productivity in the agricultural sector causing increased output and index of production in the sector, some of the selected monetary policy instruments did not yield the expected results.

Here also, Money Supply is statistically significant while the Treasury Bill Rate (TBR) and the Minimum Rediscount Rate (MRR) are not statistically significant.

It is evident from the regression results that the central bank has failed to utilize the monetary policies to stimulate productivity in the agricultural sector. Despite the various programmes and schemes that the central bank has implemented over the years to support her monetary policies, considerable development has not been noticed in the agricultural sector. One of the factors that is responsible for this is policy inconsistency. Policy inconsistency often sends the wrong signals to stakeholders in agriculture and prevents private sector long term capital investment that could engender increased productivity in the agricultural sector. Frequent policy reversals also result in non-response to government policies by stakeholders.

A nation is not maximizing the productivity of its resources unless it is employing all of them efficiently, not just some of them. As agriculture had been the mainstay of the Nigerian economy before the oil boom, it is in the national interest that agriculture should be given adequate attention now, so as to ensure a stable economy when the oil market collapses. It is high time that the government critically analyses the problems confronting the sector and develop policies that would have direct impact on farmers' productivity.

\subsubsection{How do the monetary policy instruments affect agricultural sector in Nigeria?}

The impact of monetary policy instruments on the performance of the agricultural sector in Nigeria has been captured by the two models estimated in the regression analysis. The performance of the agricultural sector was measured by the output of the agricultural sector and index of agricultural production, while the three major monetary policy instruments that were considered in the analysis include: Minimum Re-discount Rate and Treasury Bill Rate, and Money supply. It was found that although the selected monetary policy instruments have stimulated productivity in the agricultural sector causing increased output and index of production in the sector, some of the selected monetary policy instruments did not exert the expected impact. This suggests that monetary policies have not been fully effective in accelerating the development of the agricultural sector.

\section{Summary, Conclusion And Recommendations}

This research work studied the impact of monetary policies on agricultural development in Nigeria between 1970 and 2010. The CBN's monetary policies played an indispensable role in Nigerian agricultural sector by regulating and stabilising the amount of money in circulation in order to provide an enabling environment for investment, which will foster economic development without inconveniencing other sectors. The literature review highlighted the various definitions of monetary policy delivered by different scholars ranging from the classical economists to contemporary economists. And the Least Square method was used. The data used were secondary in nature and were collected from the CBN's annual statistical bulletin of various years. The adoption of various monetary policy measures by the Central Bank of Nigeria has not recorded significant progress in terms of providing enabling environment for better performance in the agricultural sector. A lot still needs to be done in the areas of creating public awareness, improving operation of the financial market and enhancing the depth and breadth of the market and building regulatory capacity so as to appropriately position the market to face the challenges ahead.

\section{Conclusion}

The role of the CBN's monetary policies as the tools for regulating the liquidity state of the economy which affects some macroeconomic indicators such as the inflation rate, lending rate, interest rate, etc. cannot be over-emphasised. The Central Bank of Nigeria has gone a long way in providing the right environment for economic development by agitating for small scale loan to agricultural sector. However, the doctrine that the agricultural sector is the least in the developmental ladder can be noted as the reason for the neglect of the sector 
for the oil sector. As a matter of fact, the Agricultural sector is the bedrock of any economy and cannot be totally neglected. It is important that the Central Bank's monetary policies are structured in such a way that the productivity of the sector is better encouraged.

In the light of the regression results, it is evident that the monetary policies have not been fully effective in accelerating the development of the agricultural sector. Besides, the small-scale loan to agricultural sector scheme has not also fulfilled the purpose for which it was meant. The scheme need be re-directed in favour of the agricultural sector and the government needs to set and integrate all forces in motion to encourage the participants in the Agricultural sector.

\section{Recommendations}

Based on the findings of this study, particularly the results of the regression models, it is clear that the development of the Nigerian economy is highly dependent on the provision of the right environment for investment, which will in no doubt encourage economic development. The following recommendations are consequently made. The Central Bank of Nigeria should:-

Make the monetary policies the preferred efficient provider of favourable environment in terms of the implementation of the appropriate interest rate, exchange rate, etc. in order to attract both domestic and foreign investment to the agricultural sector. However, in order to maintain and exploit the current investment climate, the Central Bank of Nigeria should introduce more monetary instruments that are flexible enough to meet the demands of the agricultural sector. This will allow for the existence of different measures that will deal with different situations. The Central Bank should make more stringent punishment for non-compliance to the monetary policies by financial institutions.

The primary limitation/problem faced in the course of this research was availability of data.

\section{References}

[1] M. Friedman, (1969) [1]. "The Role of Monetary Policy.” The Optimum Quantity of Money, ed. Milton Friedman. Chicago: Aldine. [2] M. Friedman, and A. Schwartz, (1963) [2]. "Money and Business Cycles". Review of Economics and Statistics, Februray, pp. $32-$ 64.

[3] M. Gertler, and S. Gilchrist, (1991) [3]. "Monetary Policy, Business Cycles and the Behaviour of Small Manufacturing Firms," WP 3892, National Bureau of Economic Research, Cambridge, November.

[4] J. Tobin, (1978) [4]. "Monetary Policy and the Performance of Commercial Banks in Nigeria, Economic and Financial Review, Central Bank of Nigeria, Vol. 33, No. 2, pp. 156-170.

[5] C.E.V. Borio, (1995) [5]. "The Structure of Credit to the Non-government Sector and the Transmission Mechanism of Monetary Policy: A Cross-Country Comparison”. Bank for International Settlement Working Paper, Basle, April.

[6] E. Shaw, (1973) [6]. Financial Deeping in Economic Development, New York: Oxford University Press.

[7] K.F. Duncan, and M. Sidrauski, (1971) [7]. Monetary and Fiscal Policy in a Growing Economy.

[8] Eze, F.U. (1993). "Open Market Operations: the progress so far”, CBN Bullion, Vol.17, No. 3. July/September.

[9] K. Jokomba, and K. Fasanu, (1998) [8]. "A Monetary Policy in a War Economy: The Nigerian Experience. Social and Economic Studies 21 No. 3, 338B47.

[10] T. Ufodiama, (1999) [9]. “An Appraisal of special Treasury bill (STBs) as an instrument in 1999 Monetary Operation’Union Digest Vol.5. NO.2.pp.12-21

[11] J.C. Anyanwu (1996) [10], Monetary Economics: Theory, Policy and Institutions. Hybrid publishers limited.

[12] M. Ahmed, (1991) [11]. "Fiscal and Monetary Policies in a Deregulated Banking Environment."

[13] In Nigerian Banking and Finance Industry in Transition: Shaping the Future: 1992 Bank Directors' Seminar: Papers and Proceedings. Yaba, Lagos: Financial Institutions Training Centre.

[14] F.U. Eze, (1993) [12] “Open Market Operations: the progress so far”, CBN Bullion, Vol. 17, No.3. July/September.

[15] C.I. Kogar, (1995) [13]. "Financial Innovations and Monetary Control". The Central Bank of The Republic of Turkey Discussion Paper No: 9515, May.

[16] E. Canetti, and J. Greene, (2000) [14]. "Monetary Growth and Exchange Rate Depreciation as Causes of Inflation in African Countries". Centre for Economic Research on Africa, September.

[17] M.A. Iyoha, and D. Oriakhi, (2002) [15]. "Explaining African Economic Growth Performance: The Case of Nigeria." A Revised Interim Report on Nigerian Case Study prepared for the African Economic Research Consortium Research, May.

[18] O.J. Nnanna, (2001) [16]. "Monetary policy framework in africa: The Nigerian experience". Central Bank of Nigeria, Abuja, July.

[19] D.T. Busari, P.C. Omoke, and B. Adesoye, (2006) [17]. "Monetary policy and macroeconomic stabilization under Alternative exchange rate regime: evidence from Nigeria".

[20] N. Batini, (2004) [18]. "Achieving and Maintaining Price Stability in Nigeria”. IMF Working Paper WP/04/97, June.

[21] A.O. Folawewo, and T.S. Osinubi, (2006) [19]. "Monetary Policy and Macroeconomic Instability in Nigeria: A Rational Expectation Approach". Journal of Social Science, vol.12(2): pp.93-100.

[22] J.O. Sanusi, (2002) [20]. "Central Bank and the macroeconomic environment in Nigeria". Being a lecture delivered to participants of the Senior executive course No. 24 of the national Institute for policy and strategic studies (NIPSS), Kuru on 19th august. 
APPENDIX

Regression Data for The Impact of Monetary Policy on Agricultural Development in Nigeria (1970- 2010)

\begin{tabular}{|c|c|c|c|c|c|c|c|c|c|c|}
\hline Year & $\begin{array}{c}\text { gutggx } \\
\text { (million tounes) }\end{array}$ & indagr1990 & $\begin{array}{l}\operatorname{mrr}_{* 1: 1} \\
(90)\end{array}$ & $\begin{array}{l}\mathrm{tbr}_{3-1} \\
(90)\end{array}$ & $\begin{array}{c}\mathrm{m}_{\mathrm{s \rightarrow 1}-1} \\
\text { (N)millipg) }\end{array}$ & $\begin{array}{c}\log \\
\text { putggx }\end{array}$ & $\begin{array}{c}\log \\
\text { indagr } 1990 \\
\end{array}$ & $\begin{array}{l}\log \\
\operatorname{mrr}_{s-1} \\
\end{array}$ & $\begin{array}{l}\log _{2} \\
\text { tbr }\end{array}$ & $\begin{array}{l}\log _{5} \\
m_{\mathrm{m}:-1}\end{array}$ \\
\hline 1970 & 37.00880 & 7522 & 450 & 400 & 548.41 & 1.57 & 19 & 65 & 60 & 2.74 \\
\hline 1971 & 32.71260 & 68.18 & 450 & 400 & 789.56 & 151 & 8 & 65 & 60 & 290 \\
\hline 1972 & 25.26720 & 56.12 & 450 & 400 & 97193 & 1.40 & 1.7 & 65 & 60 & 299 \\
\hline 1973 & 28.14230 & 61.01 & 450 & 400 & 1,05582 & 1.45 & 1.8 & 65 & 60 & 3.02 \\
\hline 1974 & 3407540 & 7087 & 450 & 400 & 1,26599 & 1.53 & 19 & 65 & 60 & 3.10 \\
\hline 1975 & 28.806 & 62.27 & 450 & 400 & $1,753,72$ & 1.46 & 8 & 65 & 60 & 324 \\
\hline 1976 & 25952 & 58.27 & 4 & 3.5 & $3,031,33$ & 41 & 18 & 60 & 54 & 3.48 \\
\hline 1977 & 253471 & 57.73 & 3.50 & 250 & 4.510 .55 & 1.40 & 1.8 & 54 & 40 & 3.65 \\
\hline 1978 & 239311 & 55.82 & 400 & 3.00 & $6,147.00$ & 138 & 1.7 & 60 & 48 & 3.79 \\
\hline 1979 & 23.1772 & 55.16 & 5.00 & 400 & $7,392.76$ & 137 & 1.7 & 70 & 60 & 3.87 \\
\hline 1980 & 23.7345 & 5522 & 5.00 & 400 & 9.185 .80 & 138 & 1.7 & 70 & 60 & 396 \\
\hline 1981 & 24.140 & 56.84 & 6.00 & 5.00 & $11,856.60$ & 138 & 1.8 & 78 & 70 & 407 \\
\hline 1982 & 24672 & 58.69 & 6.00 & 5.00 & 14.471 .17 & 139 & 1.8 & 78 & 70 & 4.16 \\
\hline 1983 & 14496 & 56.06 & 8.00 & 7.00 & $15,786.74$ & 1.16 & 1.7 & 90 & 85 & 420 \\
\hline 1984 & 37395 & 59.7 & 8.00 & 7.00 & 17,68793 & 157 & 1.8 & 90 & 85 & 425 \\
\hline 1985 & 39913 & 62.45 & 10.00 & 850 & 20,10594 & 1.60 & 1.8 & 1.00 & 93 & 430 \\
\hline 1986 & 41.712 & 64.66 & 10.00 & 8.50 & 22,29924 & 1.62 & 1.8 & 1.00 & 93 & 435 \\
\hline 1987 & 462.7 & 669 & 1000 & 8.50 & $23,806.40$ & 1.67 & 1.8 & 1.00 & 93 & 438 \\
\hline 1988 & 56.864 & 6929 & 12.75 & 11.75 & $27,573.58$ & 1.75 & 1.8 & 1.11 & 1.07 & 444 \\
\hline 1989 & 63.526 & 95.14 & 12.75 & 11.75 & $38,356.80$ & 1.80 & 20 & 1.11 & 1.07 & 458 \\
\hline 1990 & 67328 & 100 & 18.50 & 1750 & 45,90288 & 1.83 & 20 & 1.27 & 124 & 466 \\
\hline 1991 & 79.473 & 11154 & 1850 & 1750 & $52,857.03$ & 190 & 20 & 1.27 & 124 & 4.72 \\
\hline 1992 & 87312 & 11922 & 1450 & 15.00 & 75.401 .18 & 194 & 2.1 & 1.16 & 1.18 & 488 \\
\hline 1993 & 90.147 & 12259 & 1750 & 21.00 & 111,11231 & 195 & 2.1 & 1.24 & 1.32 & 5.05 \\
\hline 1994 & 93250 & 126.42 & 26.00 & 2690 & $165,338.75$ & 197 & 2.1 & 1.41 & 43 & 522 \\
\hline 1995 & 95556 & 128.49 & 1350 & 1250 & $230,292.60$ & 198 & 2.1 & 1.13 & 1.10 & 536 \\
\hline 1996 & 100971 & 13443 & 1350 & 1250 & 289.09107 & 200 & 2.1 & 1.13 & 1.10 & 5.46 \\
\hline 1997 & 103.859 & 137.73 & 13.50 & 1225 & 345,85396 & 2.02 & 2.1 & 1.13 & 1.09 & 5.54 \\
\hline 1998 & 107.703 & 141.04 & 1350 & 1200 & $413,280.13$ & 203 & 2.1 & 1.13 & 1.08 & 5.62 \\
\hline 1999 & 111515 & 1452 & 1431 & 1295 & $488,145.79$ & 2.05 & 22 & 1.16 & 1.11 & 5.69 \\
\hline 2000 & 1178.876 & 1492 & 18.00 & 17.00 & $628,952.16$ & 2.07 & 2.2 & 1.26 & 1.23 & 580 \\
\hline 2001 & 103.635 & 1489 & 13.50 & 12.00 & 878,45727 & 2.02 & 22 & 1.13 & 1.08 & 594 \\
\hline 2002 & 1075725 & 1799 & 1431 & 1295 & $1,269,321.61$ & 2.03 & 23 & 1.16 & 1.11 & 6.10 \\
\hline 2003 & 1153041 & 1909 & 1900 & 18.88 & $1,508,17291$ & 2.06 & 23 & 128 & 128 & 6.18 \\
\hline 2004 & 125.0849 & 201.8 & 15.75 & 15.02 & $1,952,92228$ & 2.10 & 23 & 120 & 1.18 & 629 \\
\hline 2005 & 1295335 & 1869 & 15.00 & 1421 & $2,131,820,08$ & 2.11 & 23 & 1.18 & 1.15 & 633 \\
\hline 2006 & 1346303 & 200.1 & 13.00 & 7.00 & $2,637,913.73$ & 2.13 & 23 & 1.11 & 85 & 6.42 \\
\hline 2007 & 1435977 & 2128 & 1225 & 8.80 & $3,799.53805$ & 2.16 & 23 & 1.09 & 94 & 658 \\
\hline 2008 & 1539694 & 226.7 & 8.75 & 691 & $5,138,70094$ & 2.19 & 2.4 & 94 & 84 & 6.71 \\
\hline 2009 & 1635082 & 242.1 & 9.81 & 7.02 & $8,029,088.61$ & 221 & 2.4 & 99 & 85 & 690 \\
\hline 2010 & 1729397 & 2559 & 7.44 & 3.71 & $9,456,480,31$ & 2.24 & 2.4 & 87 & 57 & 698 \\
\hline
\end{tabular}

Source:Central Bank of Nigeria Statistical Bulletin; Central Bank of Nigeria Annual Report and Statement of Accounts for various years

\section{MODEL I}

\section{ORDINARY LEAST SQUARE ANALYSIS ON EVIEWS}

\begin{tabular}{|c|c|c|c|c|}
\hline \\
\hline & & & & \\
\hline \multicolumn{4}{|c|}{$\begin{array}{l}\text { Dependent Variable: LOGOUTAGR } \\
\text { Method: Least Squares }\end{array}$} & \\
\hline \multicolumn{4}{|c|}{ Sample: $19702010^{--}$} & \\
\hline \multicolumn{5}{|c|}{ Included observations: $41^{-}$} \\
\hline Variable & Coefficient: & Std. Error & t-Statistic & Prob: \\
\hline $\mathrm{C}$ & 0.594340 & $0.098250^{\prime}$ & 6.049279 & 0.0000 \\
\hline $\mathrm{LOG} m r r_{t-1}$ & & 0.611573 & & 0.8568 \\
\hline $\mathrm{LOGtbr} r_{t-1}$ & 0.160251 & 0.470413 & 0.340660 & 0.7535 \\
\hline $\mathrm{LOG} m_{2 t-1}$ & 0.192157 & 0.033346 & 5.762443 & 0.0000 \\
\hline R-squared & 0.842828 & Mean depend & & 1.775366 \\
\hline Adjusted R-squared & 0.830085 & S.D. depende & & 0.309436 \\
\hline SE. of regression & 0.127552 & Alaike info 0 & erion & 11888119 \\
\hline Sum squared regd & 0.601971 & Schwarz crite & & -1.020942 \\
\hline Log likelihood & 28.35645 & F-statistic & & 66.13710 \\
\hline Durbin-Watson stat & 0.545256 & $\mathrm{Prob} / \mathrm{F}$-statist & & 0.000000 \\
\hline
\end{tabular}






\begin{tabular}{|c|c|c|c|c|}
\hline \multicolumn{5}{|c|}{ 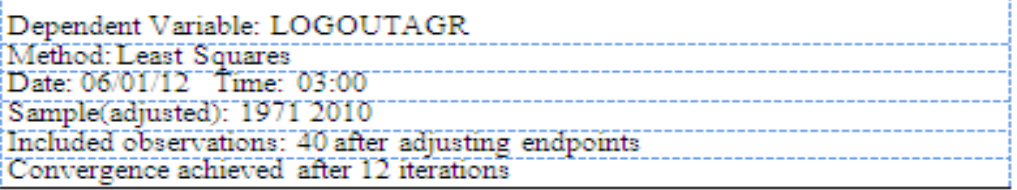 } \\
\hline Variable & Coefficient: & Std. Error & t-Statistici & Prob. \\
\hline$\frac{\mathrm{C}}{\mathrm{LOG} m r_{t-1}}$ & $\begin{array}{l}0.464275 \\
0.098355 \\
\end{array}$ & & $\begin{array}{l}2.166974 \\
0.262270\end{array}$ & $\begin{array}{l}\mid 0.0371 \\
0.7947\end{array}$ \\
\hline$\overline{\mathrm{LOG}} t \bar{b} r_{t-1}$ & 0.020669 & 0.282563 & 0.073148 & 0.9421 \\
\hline $\mathrm{LOG} m_{2 t-1}$ & 0.241624 & 0.042380 & 5.701320 & 0.0000 \\
\hline$A R(1)$ & 0.700994 & 0.102128 & 6.863870 & 0.0000 \\
\hline 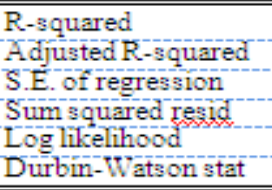 & \begin{tabular}{|c|}
0.936518 \\
0.929263 \\
0.082876 \\
0.240393 \\
45.52963 \\
2.234436 \\
\end{tabular} & $\begin{array}{l}\text { Mean depend } \\
\text { S.D. depende } \\
\text { Akaike info } \\
\text { Schwarz crite } \\
\text { F-statistic } \\
\text { Prob }- \text { F-statist }\end{array}$ & $\begin{array}{l}\text { yar } \\
\text { var } \\
\text { anion } \\
\text { nn }\end{array}$ & \begin{tabular}{|l|}
1.780500 \\
0.311604 \\
-2.026481 \\
-1.815371 \\
129.0842 \\
0.000000 \\
\end{tabular} \\
\hline Inverted AR Roots & .70 & & & \\
\hline
\end{tabular}

\section{MODEL II}

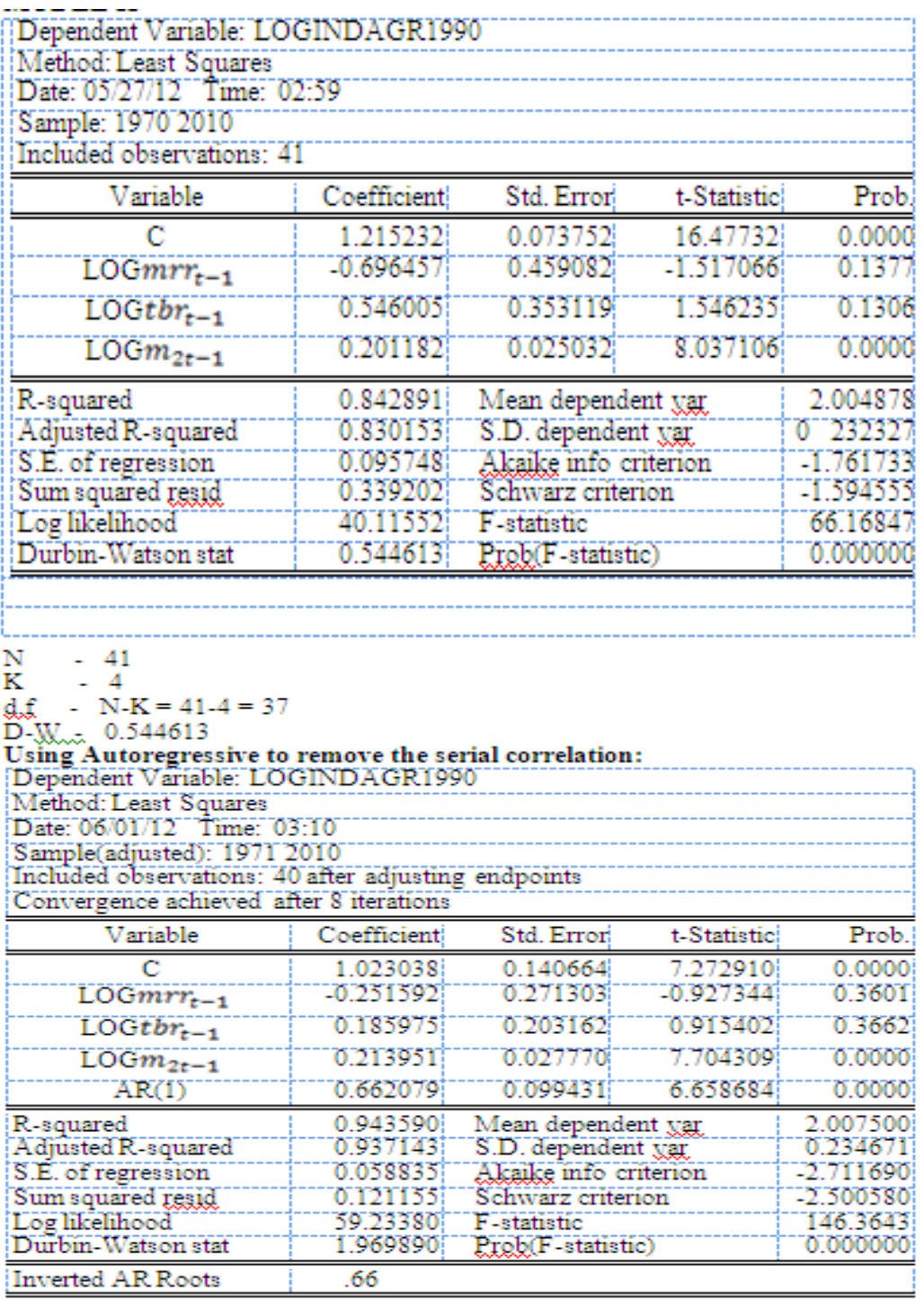

